\title{
Ethical problems in study of total institutions
}

\section{Problemy etyczne w badaniach instytucji totalnych}

\author{
Andrzej Borowski \\ Katedra Socjologii i Pracy Socjalnej, Wydział Edukacyjno-Filozoficzny, \\ Akademia Pomorska w Słupsku, ul. Westerplatte 64, 76-200 Słupsk, Poland \\ E-mail address: aubor@poczta.onet.pl
}

\begin{abstract}
Occurrence of ethical problem is forced them in research of total institutions by character. It belongs to biggest ethical problems in case of total institution in the course of research: - protection privacy respondent and at publication of result in accordance with staff; - behavior neutrality equal as well as subordinates; - disclosure secret environmental. Concentration on variable, which limit subjectivism of collected data has in research of total institutions in forceful winning objective data about functioning in accordance with society of reality ethical dilemmas meaning this exclusive not increasing simultaneously.
\end{abstract}

Keywords: total institution; ethics; exclusiveness; protection of privacy; double neutrality

\section{STRESZCZENIE}

Występowanie problemów etycznych w badaniach instytucji totalnych wymuszone jest przez sam ich charakter. W przypadku instytucji totalnych do największych problemów etycznych należy; ochrona prywatności respondentów w trakcie badań i przy publikacji wyników; - zachowanie neutralności zarówno wobec personelu jak i podwładnych; - ujawnianie tajemnic środowiskowych. Koncentracja na zmiennych, które ograniczają subiektywizm zbieranych danych nie potęgując jednocześnie dylematów etycznych $\mathrm{w}$ badaniach instytucji totalnych ma znaczenie w skutecznym pozyskiwaniu obiektywnych danych o funkcjonowaniu tych ekskluzywnych wobec społeczeństwa rzeczywistości.

Stowa kluczowe: instytucje totalne, etyka, ekskluzywność, ochrona prywatności, podwójna neutralność.

\section{WPROWADZENIE}

Występowanie problemów etycznych w badaniach instytucji totalnych wymuszone jest przez sam ich charakter. W nieodległym okresie czasu część instytucji totalnych/ koszary 
wojskowe, zakłady poprawcze, szpitale psychiatryczne, zakłady karne, okręty, seminaria duchowne, klasztory mogły być badane jedynie przez osoby zatrudnione lub polecane przez „resortowe” placówki badawcze. W znacznym stopniu utrudniało to możliwości nieskrępowanych badań akademickich. Dopiero w ostatnich latach podaje się do publicznej wiadomości informacje o przypadkach śmierci pensjonariuszy instytucji totalnych oficjalnie zakwalifikowanych jako samobójstwa, które okazują się czasami zwykłymi zabójstwami. Na szczęście są to przypadki odosobnione.

\section{TEORETYCZNY ASPEKT PRZEDMIOTU BADAŃ}

Pobyt $\mathrm{w}$ instytucji totalnej wynika zazwyczaj $\mathrm{z}$ unormowań prawnych, bądź $\mathrm{z}$ wewnętrznych potrzeb człowieka. Mimo zachodzących w Polsce głębokich zmian ustrojowych i społecznych sfera funkcjonowania instytucji nazywanych totalnymi pozostaje jednym $\mathrm{z}$ trudniejszych metodologicznie obszarów badawczych. Na sytuację taką w niemałym stopniu składa się specyfika tychże instytucji/ zwłaszcza programowe wyizolowanie ze środowiska zewnętrznego/ jak również niechęć większości badaczy do rozwijania koncepcji metodologicznych w tej dziedzinie.

Tymczasem, jak zauważył S. Amsterdamski ":...moja etyka to moja metodologia. Póki nie grzeszę przeciwko regułom gry obowiązującym w nauce, a kodyfikowanym przez filozofię nauki, spełniam zarazem i mój zawodowy obowiązek uczonego i etyczny obowiązek człowieka" [1].

$\mathrm{W}$ badaniach prowadzonych $\mathrm{w}$ instytucjach totalnych celna jest również inna uwaga tego autora: ,problemem etycznym jest nie tylko i nie tyle akceptacja określonej normy etycznej, lecz również, z może przede wszystkim rozpoznanie sytuacji empirycznej, w której dana norma powinna być stosowana lub zawieszona. Każdy człowiek/ nie tylko uczony rozwiązywać musi ten problem na własną odpowiedzialność nie licząc, że jakakolwiek ogólna zasada wybawi go z tej mało komfortowej sytuacji” [2].

Dokonując wyboru przedmiotu badań uczony musi mieć świadomość, iż za jego decyzją w tej sprawie zawsze będą się kryć jakieś wartości. „Fikcją są badania czyste, wolne od wartościowania. Wartościowanie najtrudniej jest odrzucić właśnie w badaniach społecznych" zauważa analizując metody badawcze E. Nowicka [3].

Prowadząc badania $\mathrm{w}$ instytucji totalnej, uczony musi być przygotowany do rozwiązania najważniejszych problemów natury etycznej z jakimi spotka się w miejscu badań. W przypadku instytucji totalnych do największych problemów etycznych należy:

- - ochrona prywatności respondentów w trakcie badań i przy publikacji wyników

- - zachowanie neutralności zarówno wobec personelu jak i podwładnych

- - ujawnianie tajemnic środowiskowych.

W zakresie ochrony prywatności respondentów badacz musi być świadomy, iż w każdej instytucji totalnej funkcjonują struktury nieformalne/ $\mathrm{w}$ literaturze przedmiotu nazywane ,drugim życiem instytucji”

Społeczność instytucji totalnej tworzy zamknięty krąg, w którym bardzo trudno jest zachować anonimowość a pozyskiwanie informacji o podwładnych przez personel i o słabostkach personelu przez podwładnych należy do normalnych/ choć nie do końca formalnych/ czynności podejmowanych przez osoby przebywające $\mathrm{w}$ takiej instytucji.

W związku z powyższym publikacja wyników badań w minimalnym stopniu chroni prywatność i anonimowość respondentów. W prowadzonych badaniach można spotkać się 
nawet z przypadkami umyślnego „podsyłania” wybranych wcześniej/ zaufanych personelu/ respondentów, celem zdobycia informacji o potencjalnych ukrytych/ przed personelem/ intencjach badacza. Dlatego też badacze wykazują nikłe zainteresowanie prowadzeniem badań w samych instytucjach totalnych, zaś obowiązek przestrzegania przez personel instytucji totalnych określonych norm etycznych i praw podwładnych egzekwują bezpośredni przełożeni, organa i instytucje społecznego nadzoru a ostatnio również rodziny podwładnych.

Drugim niezmiernie trudnym i koncentrującym uwagę problemem etycznym $\mathrm{w}$ badaniach instytucji totalnych jest umiejętność zachowania podwójnej neutralności -wobec personelu i podwładnych. Z aspektu poprawności metodologicznej wszystko jest $\mathrm{w}$ jak najlepszym porządku. Biorąc jednak pod uwagę specyficzny przedmiot badań, który standardowo jest wyizolowany z rzeczywistości społecznej i potrzebę analizy takich sfer działalności instytucji totalnych, które są uznane za niedostępne dla osób postronnych, badacz stoi przed problemem uzyskania własnej wiarygodności w oczach respondentów.

Należy przy tym pamiętać iż respondentami w instytucji totalnej jest zarówno personel jak i podwładni. Grupy te są z reguły w mniejszym lub większym stopniu zantagonizowane i nastawione wobec siebie $\mathrm{z}$ dużą dozą nieufności. Badacz powinien mieć świadomość, że wzbudzając zaufanie członków jednej grupy automatycznie może zacząć budzić podejrzenia o stronniczość wśród członków drugiej grupy. Pomijam przy tym zróżnicowanie samej społeczności podwładnych, co $\mathrm{w}$ niektórych rodzajach instytucji totalnych ma również ogromne znaczenie/ patrz: zróżnicowanie relacji wobec personelu poszczególnych grup nieformalnych w zakładach karmnych/.

Postawa neutralności wobec obu kategorii/ personelu i podwładnych/ jest optymalnym rozwiązaniem, gdyż każda inna forma ogranicza lub wręcz uniemożliwia przeprowadzenie poprawnych metodologicznie badań. Ukrywanie swojej postawy wobec którejkolwiek z tych kategorii może skutkować odmową udziału w badaniach/ podwładni/, bądź uniemożliwieniem ich przeprowadzenia /personel/.

Podczas prowadzenia badań w instytucji totalnej badacz spotkać się może z szeregiem różnych ograniczeń/ zakazów nakazów/ wynikających zarówno z formalno prawnych uregulowań jak i wpływu struktur nieformalnych. Większość z tych ograniczeń stanowiących o istocie instytucji funkcjonuje jako swoista tajemnica grupowa, zawodowa czy służbowa. Dostęp do tajemnicy mogą posiadać wyłącznie osoby do tego uprawnione i uznane za wiarygodne i odpowiedzialne. Odpowiedzialność jest tutaj rozumiana jako zakaz rozmów na tematy objęte tajemnicą $\mathrm{z}$ osobami postronnymi. Oczekuje się, że zarówno personel jak i podwładni we wszystkich instytucjach totalnych zastosują się do tego wymogu. Bardziej wnikliwi badacze aby dojść prawdy stosują różne zabiegi socjo- i psychotechniczne.

Udzielenie przez respondenta/ niezależnie od kategorii przynależności/ informacji objętych tajemnicą środowiskową jest traktowane jako zdrada środowiska i ostro potępiane. Rodzi to oczywiście niechęć do udzielania prawdziwych informacji badaczowi, gdy mógłby paść na respondenta choćby cień podejrzenia, że ujawnia taką tajemnicę. System funkcjonujący w większości instytucji totalnych wymusza od personelu i podwładnych posłuszeństwo wobec przełożonych a nie szczerość. Odpowiadając na zasygnalizowane problemy etyczne zaproponowałem nowe podejście do badań w instytucjach totalnych, które minimalizowałoby występowanie rozterek etycznych [4].

W podejściu tym skupiam się wokół kwestii barier, izolacji, różnych form ubezwłasnowolnienia i zdefiniowania pojęcia totalności instytucji. Podstawowe bariery występujące w instytucjach totalnych można podzielić na: 
A) Bariery fizyczne:

a) naturalne:

- lądolód, pustynia, las, wysokie góry

- woda

- głębia morska, ziemia

- przestrzeń kosmiczna

b) sztuczne:

- zasieki z drutu kolczastego, siatka, uniform, obroża

- krata, żywopłot, płot,

- drzwi, mur, most zwodzony

B) Bariery symboliczne:

a) regulamin pobytu, żargon

b) ostracyzm, stygmatyzacja, izolacja psychiczna/ wyuczona bezradność/

c) izolacja medyczna/kwarantanna/,izolacja religijna/klauzura/, izolacja prawna/ zakaz wstępu/, izolacja społeczna/ brak łączności i dostępu do informacji z zewnątrz/

W przezwyciężaniu barier związanych z określonym rodzajem instytucji totalnej duże znaczenie ma określenie stopnia totalności instytucji. Wyraźne określenie takiego stopnia pomaga we właściwym przystosowaniu się osoby niepełnosprawnej do warunków życia w instytucji.

Przez totalność instytucji rozumiem - ograniczenie możliwości dokonywania wyborów i podejmowania samodzielnych decyzji, przejęcie kontroli nad czasem i przestrzenią w której funkcjonują podopieczni, zaanektowanie, ubezwłasnowolnienie, realizowane w warunkach izolacji. Stopień totalności jest średnią arytmetyczną stopnia ubezwłasnowolnienia i stopnia izolacji. Stopień ubezwłasnowolnienia jest odwrotnie proporcjonalny do wielkości enklawy wolności $w$ uniwersum przymusu. Im ta enklawa jest mniejsza tym stopień ubezwłasnowolnienia jest większy. Wielkość wspomnianej enklawy można mierzyć w skali jednego dnia poprzez użycie wskaźnika jakim jest ilość czasu wolnego/ do zagospodarowania według własnego uznania przez członków/ pensjonariuszy/ instytucji totalnej, mierzonego w godzinach. $\mathrm{P} / \mathrm{u} /=1 / \mathrm{w}$, gdzie $\mathrm{P} / \mathrm{u} /$ jest stopniem ubezwłasnowolnienia, a $\mathrm{w}$ wielkością enklawy wolności w uniwersum przymusu. Gdy wartość $\mathrm{P} / \mathrm{u} /=1$ mamy do czynienia $\mathrm{z}$ całkowitym ubezwłasnowolnieniem.

Stopień izolacyjności jest odwrotnie proporcjonalny do stopnia przepuszczalności. Im ta enklawa jest mniejsza tym stopień izolacyjności jest większy. Wielkość stopnia przepuszczalności można mierzyć w skali jednego dnia poprzez użycie wskaźników jakimi są ilość czasu/mierzonego w godzinach/ w którym:

- członkowie/pensjonariusze/ instytucji totalnej mogą z własnego wyboru przebywać poza nią /przepuszczalność ad extra/

- osoby z zewnątrz mogą przebywać na terenie instytucji totalnej kontaktując się z jej członkami/pensjonariuszami /przepuszczalność ad intra/. 


\section{WNIOSKI}

Koncentracja na zmiennych, które ograniczają subiektywizm zbieranych danych nie potęgując jednocześnie dylematów etycznych w badaniach instytucji totalnych ma znaczenie w skutecznym pozyskiwaniu obiektywnych danych o funkcjonowaniu tych ekskluzywnych wobec społeczeństwa rzeczywistości.

\section{References}

[1] S. Amsterdamski, Nauka. Technika. Etyka, w: /red. E. Nowicka M. Chałubiński, Idee a urządzanie świata społecznego, Warszawa, 1999, s. 25.

[2] S. Amsterdamski, Nauka. Technika. Etyka, w: /red. E. Nowicka M. Chałubiński, Idee a urządzanie świata społecznego, Warszawa, 1999, s. 28-29.

[3] E. Nowicka, Świat człowieka, świat kultury, Warszawa, 1998, s.1 77.

[4] A. Borowski, Instytucje religijne jako instytucje totalne, w:/red. A. Wójtowicz/ Socjologia Religii ks. W. Piwowarskiego, Warszawa, 2004, s. 133-136. 